\title{
Rediscovery of the Endangered Carchi Andean Toad, Rhaebo colomai (Hoogmoed, 1985), in Ecuador, with comments on its conservation status and extinction risk
}

\author{
Carolina Reyes-Puig ${ }^{1,11}$, Gabriela B. Bittencourt-Silva², María Torres-Sánchez ${ }^{3,4}$, Mark \\ Wilkinson ${ }^{2}$, Jeffrey W. Streicher ${ }^{2}$, Simon T. Maddock ${ }^{2,5}$, Ramachandran Kotharambath ${ }^{6}$, Hendrik \\ Müller $^{7}$, Francesca Nicole Angiolani Larrea ${ }^{8}$, Diego Almeida-Reinoso ${ }^{8,9}$, Santiago R. Ron ${ }^{8}$, \\ Diego Francisco Cisneros-Heredia ${ }^{1,2,10,11}$
}

1 Universidad San Francisco de Quito USFQ, Colegio de Ciencias Biológicas y Ambientales COCIBA, Instituto de Zoología Terrestre, Museo de Zoología, Campus Cumbayá, Quito, 17-1200-841, Ecuador. 2 The Natural History Museum, Department of Life Sciences, Cromwell Rd, Kensington, London, SW7 5BD, United Kingdom. 3 Department of Biodiversity, Ecology and Evolution, Complutense University of Madrid, 28040 Madrid, Spain. 4 Current address: Department of Neuroscience, Spinal Cord and Brain Injury Research Center \& Ambystoma Genetic Stock Center, University of Kentucky, Lexington, KY, 40536, USA. 5 University of Wolverhampton, School of Sciences, Wolverhampton, Wulfruna Street, Wolverhampton, WV1 1LY, United Kingdom. 6 Central University of Kerala, Department of Animal Science, Tejaswini Hills, Periye Post, Kasaragod, Kerala, 6711316, India. 7 Friedrich Schiller University Jena, Institute of Zoology and Evolutionary Biology, Erbertstr. 1, Jena, 07743, Germany. 8 Pontificia Universidad Católica del Ecuador, Museo de Zoología, 12 de Octubre y Vicente Ramón Roca, Quito, 17-01-2184, Ecuador. 9 Programa de Cría de Insectos en Granja SARGRILLO, Llano Chico, Quito, 170165, Ecuador. 10 King's College London, Department of Geography, Strand, London, W12, United Kingdom. 11 Instituto Nacional de Biodiversidad, Unidad de Investigación, División de Herpetología, Quito, 17-07-8976, Ecuador.

Corresponding author: Carolina Reyes-Puig, carolina_reyes.88@hotmail.com

\begin{abstract}
Since 1984 there have been no records of Rhaebo colomai (Hoogmoed, 1985) within the territory of Ecuador. This species was known from 2 localities in the province of Carchi, northwestern Ecuador, and the department of Nariño, southwestern Colombia, which were reported in 1979 and 2015, respectively. We report the recent sightings of $R$. colomai at 3 new localities in Ecuador and discuss and evaluate this species' extinction risk and conservation status.
\end{abstract}

Key words

Biodiversity threats, Bufonidae, Dracula Reserve, population decline.

Academic editor: Marcelo Gehara | Received 24 January 2019 | Accepted 30 April 2019 | Published 24 May 2019

Citation: Reyes-Puig C, Bittencourt-Silva GB, Torres-Sánchez M, Wilkinson M, Streicher JW, Maddock ST, Kotharambath R, Müller H, Larrea FNA, Almeida-Reinoso D, Ron SR, Cisneros-Heredia DF (2019) Rediscovery of the Endangered Carchi Andean Toad, Rhaebo colomai (Hoogmoed, 1985), in Ecuador, with comments on its conservation status and extinction risk. Check List 15 (3): 415-419. https://doi.org/10.15560/15.3.415

\section{Introduction}

The Carchi Andean Toad, Rhaebo colomai (Hoogmoed, 1985), was described on the basis of a single adult female collected in 1984 at the headwaters of the River Baboso, near Lita, province of Carchi, Ecuador. The holotype was deposited at the Naturalis Biodiversity Center, the Netherlands (RMNH 21905), formerly Rijksmuseum van Natuurlijke Historie or National Museum of Natural History, Leiden (Hoogmoed 1985, Gassó Miracle et 
al. 2007). Two additional specimens were collected with the holotype and reported to be deposited at the Museo Ecuatoriano de Ciencias Naturales (MECN 0115, 0141), but only 1 specimen remains deposited in this museum (DHMECN 0795; Hoogmoed 1989). Hoogmoed (1989) reported an older specimen collected by E. W. Schupp in 1979 near the town of Chical, also in the province of Carchi. It was deposited at the National Museum of Natural History, Smithsonian Institution, Washington, DC, USA. Thus, this species was only known from 2 localities at the River Baboso and Chical, both located on the Andean slopes of northern Ecuador, about $30 \mathrm{~km}$ apart in a straight line. This species remained known only from Ecuador until Ron et al. (2015) reported 6 males and 3 females from a population from the Reserva Natural Río Nambi, department of Nariño, Colombia. This population had been overlooked because it was previously reported as Rhaebo olallai (Hoogmoed, 1985) by Murillo-Pacheco et al. (2005). Assigning this population to $R$. colomai extended the known geographic range of the species to Colombia, approximately $40 \mathrm{~km}$ north from Chical (specimens deposited in the Herpetology Collection at Universidad de Nariño,). Since it was last seen in Ecuador in 1984, R. colomai was classified as Critically Endangered and Possibly Extinct by the IUCN Red List of Threatened Species (Coloma et al. 2004), but was categorized as Endangered in the most recent evaluation (IUCN SSC Amphibian Specialist Group 2018). We report the recent observation of adult males, adult females, and juveniles of $R$. colomai at 3 new localities in Ecuador and discuss its extinction risk and conservation status.

\section{Methods}

We discovered populations of Rhaebo colomai during expeditions carried out by 2 field teams: (i) Museo de Zoología of Pontificia Universidad Católica del Ecuador and (ii) Universidad San Francisco de Quito, the Natural History Museum, University of Wolverhampton, Complutense University of Madrid, Central University of Kerala, Friedrich Schiller University of Jena, and Instituto Nacional de Biodiversidad. We located specimens during active searches. We sacrificed the specimens by spraying benzocaine directly on the mouth, fixed them in $8 \%$ formalin, and preserved them in $70 \%$ ethanol. We determined the sex of individuals by dorsal skin texture and size, and also by direct inspection of gonads through a dorsolateral incision in collected specimens. Euthanized specimens were deposited at the Instituto Nacional de Biodiversidad (DHMECN) and Museo de Zoología, Pontificia Universidad Católica del Ecuador (QCAZ). Coordinates were obtained using a Garmin GPSMAP $64 \mathrm{~s}$ GPS receiver using the WGS84 datum. Collections were made under permits MAE-DNB-CM-2016-0045 and 002-16-IC-FAU-DNB/MA issued by Ministerio del Ambiente del Ecuador. We evaluated the extinction risk according to the IUCN (2012) guidelines. Area of

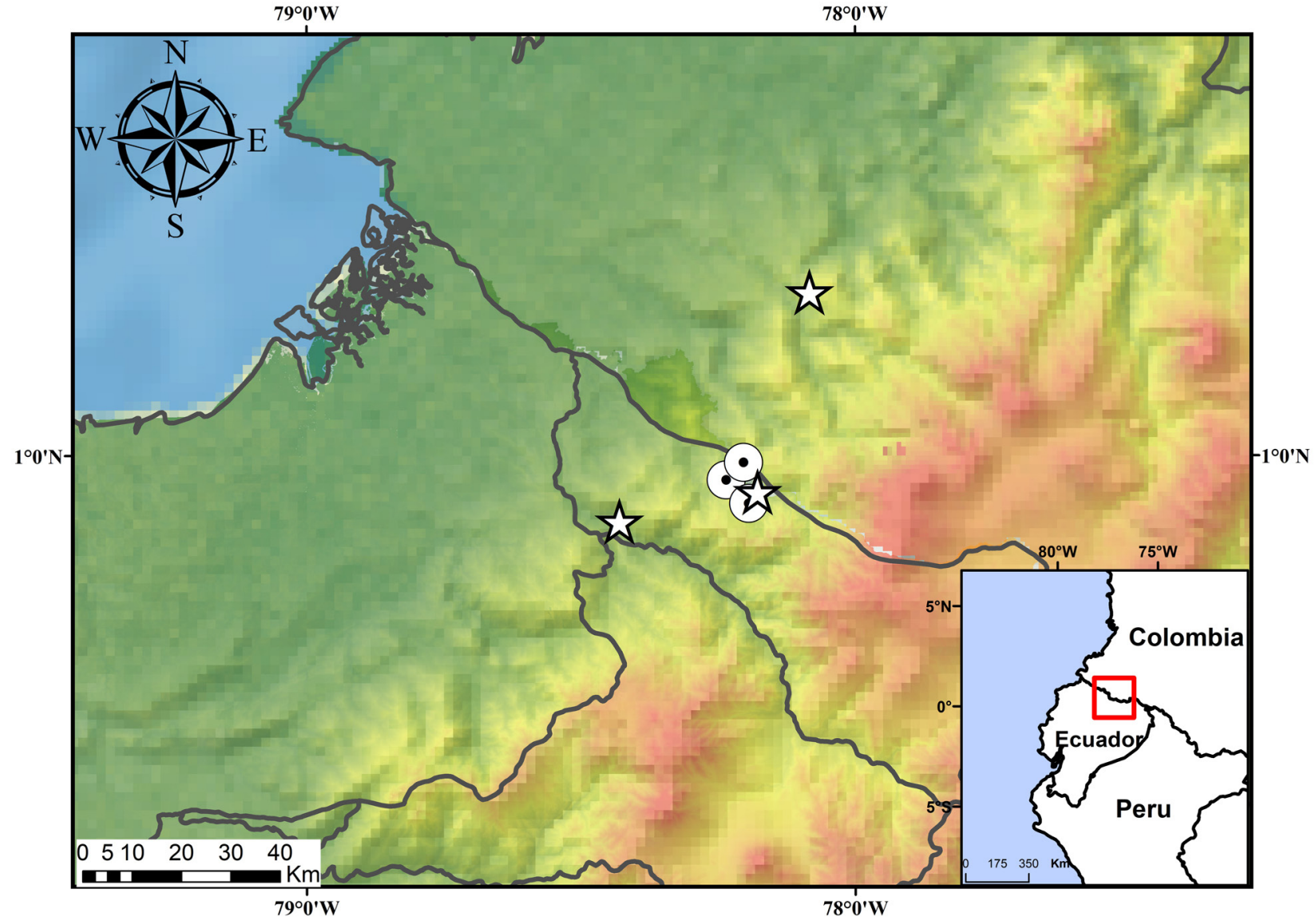

Figure 1. Known localities of Rhaebo colomai. Stars represent the previously reported records (Hoogmoed 1985, 1989, Ron et al. 2015). Circles represent the new records reported herein. 


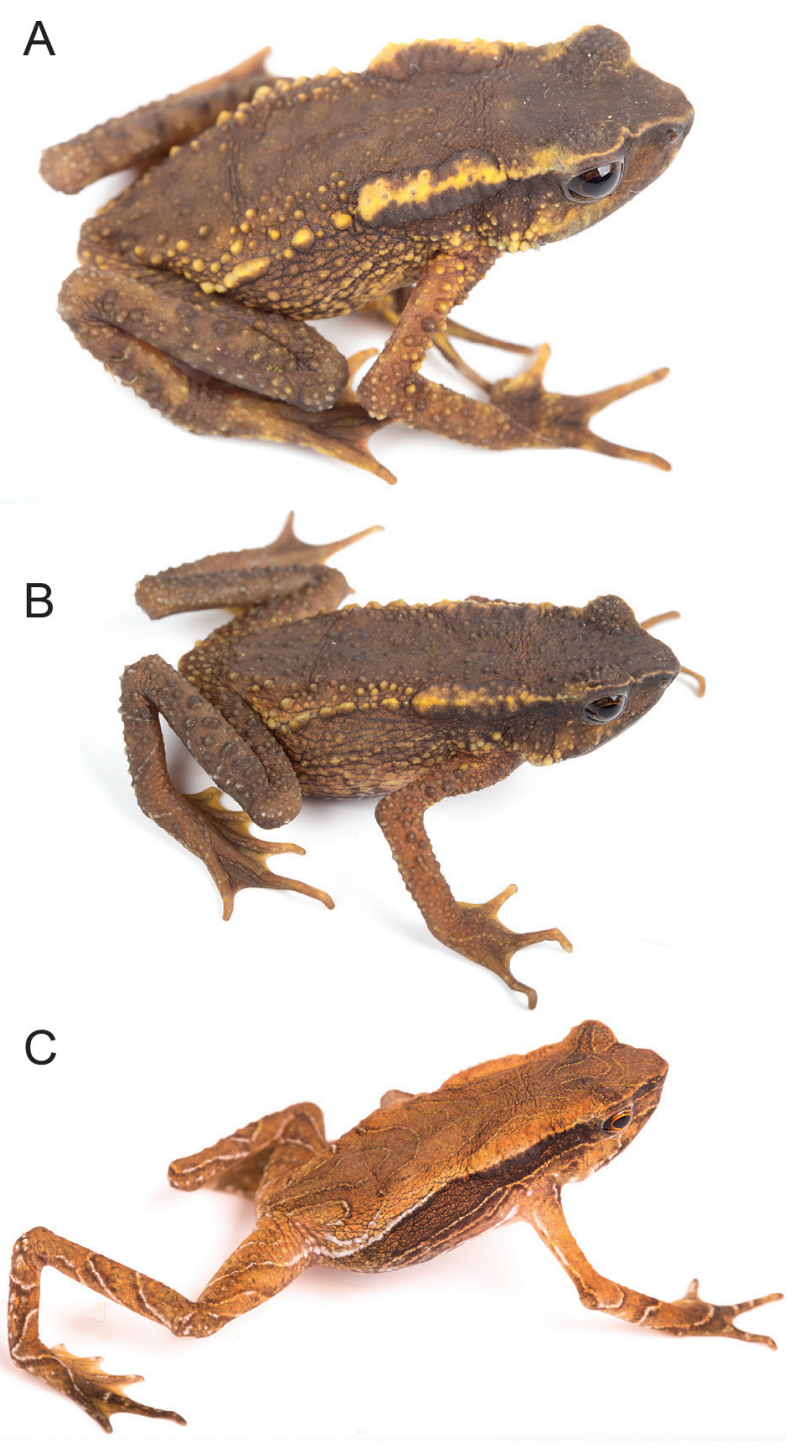

Figure 2. Rhaebo colomai. A. Adult female. B. Adult male. C. Juvenile. The individuals are at the ex-situ amphibian conservation program Balsa de los Sapos at Pontificia Universidad Católica del Ecuador. Photographs by Santiago R. Ron, BIOWEB-Ecuador.

occupancy and extent of occurrence were calculated using software GeoCAT, and an IUCN default cell width of $2 \mathrm{~km}$ was used for the analysis (IUCN 2017).

\section{Results}

New records. We discovered populations of Rhaebo colomai at three localities (Fig. 1). ECUADOR • 13 adults and 26 juveniles and subadults; province of Carchi, parish of Chical, at Río Pailón; $00^{\circ} 57.35^{\prime} \mathrm{N}, 078^{\circ} 14.12^{\prime} \mathrm{W}$; 1660 m alt.; Sept. and Dec. 2016; by Diego Almeida; found during night surveys along 2 streams (Fig. 2); 2 specimens collected and deposited, an adult female (QCAZ 67853, snout-vent length $=44.8 \mathrm{~mm}$ ) and an adult male (QCAZ 67908 snout-vent length $=35.7 \mathrm{~mm}$ ). - 1 specimen; province of Carchi, parish of Chical, at the Peñas Blancas road; 0059.20'N, 078¹1.86' W; 1088 $\mathrm{m}$ alt.; 31 July 2017; by Gabriela B. Bittencourt-Silva, Carolina Reyes-Puig, Jeffrey W. Streicher, María TorresSánchez, Simon Maddock, Ramachandran Kotharambath, Francesca Nicole Angiolani Larrea and Hendrik Müller; found at night (18h00-21h00 hrs), perching ca $1.30 \mathrm{~m}$ above ground on vegetation, near streams of crystal clear water with surrounding vegetation within wellpreserved forest; 1 specimen collected and deposited (DHMECN 13828, snout-vent length $=55.3 \mathrm{~mm}$ ). - 1 specimen; province of Carchi, parish of Chical, at Cerro Oscuro, Reserva Orquideológica Dracula; $00^{\circ}$ $54.78^{\prime} \mathrm{N}, 078.20^{\prime} \mathrm{W} ; 1303 \mathrm{~m}$ alt; 01 August 2017; by María Torres-Sánchez, Carolina Reyes-Puig, Gabriela B. Bittencourt-Silva, Jeffrey W. Streicher, Mark Wilkinson, Simon Maddock, Ramachandran Kotharambath, and Francesca N. Angiolani Larrea; found at night (18h00-21h00 hrs), perching ca $0.90 \mathrm{~m}$ above ground on vegetation, near streams of crystal clear water with surrounding vegetation within well-preserved forest; 1 specimen collected and deposited (DHMECN 13829, snout-vent length SVL= $52.0 \mathrm{~mm}$ ) (Fig. 3).

Identification. All specimens of $R$. colomai reported herein match descriptions of this species by Hoogmoed (1985, 1989) and Ron et al. (2015): flat head, projected snout, upper eyelid margin with sharp rim, elongated parotoids that produce yellow secretions, flanks with areolate skin and oblique and continuous row of small warts, long and slender limbs, webbed fingers and toes, and absent enlarged cephalic crests. Females have smooth dorsal skin, small tubercles, and a larger body size (snout-vent length 54.9-59.1 mm) while males have spiculated tubercular dorsal skin and a smaller body size (32.6-38.4 mm).

Our new observations and records from the reviewed literature show that $R$. colomai is distributed within a small area on the western Andean slopes between extreme southern Colombia and extreme northern Ecuador. This species is apparently restricted to areas in the vicinity of streams surrounded by native old-growth forests. Between the first and second visit to Río Pailón (September-December 2016), the forest was logged in a terrain adjacent to one of the streams. Nevertheless, several individuals were observed near the stream. Forest fragmentation and loss across the species' distribution is extensive, and only few forest patches remain, probably due to their inaccessibility. Habitat degradation on the western Andean slopes of the province of Carchi is extensive and continues due to expansion of agriculture.

Currently available information suggests that the extinction risk of $R$. colomai is relatively high. It is known from just 3 places: (i) River San Juan drainage, including all sites in Chical and surroundings, (ii) River Mira drainage, including the type locality at River Baboso, and (iii) River Ñambi drainage, including the only known Colombian site. Its extent of occurrence was calculated as approximately $650 \mathrm{~km}^{2}$ and its 

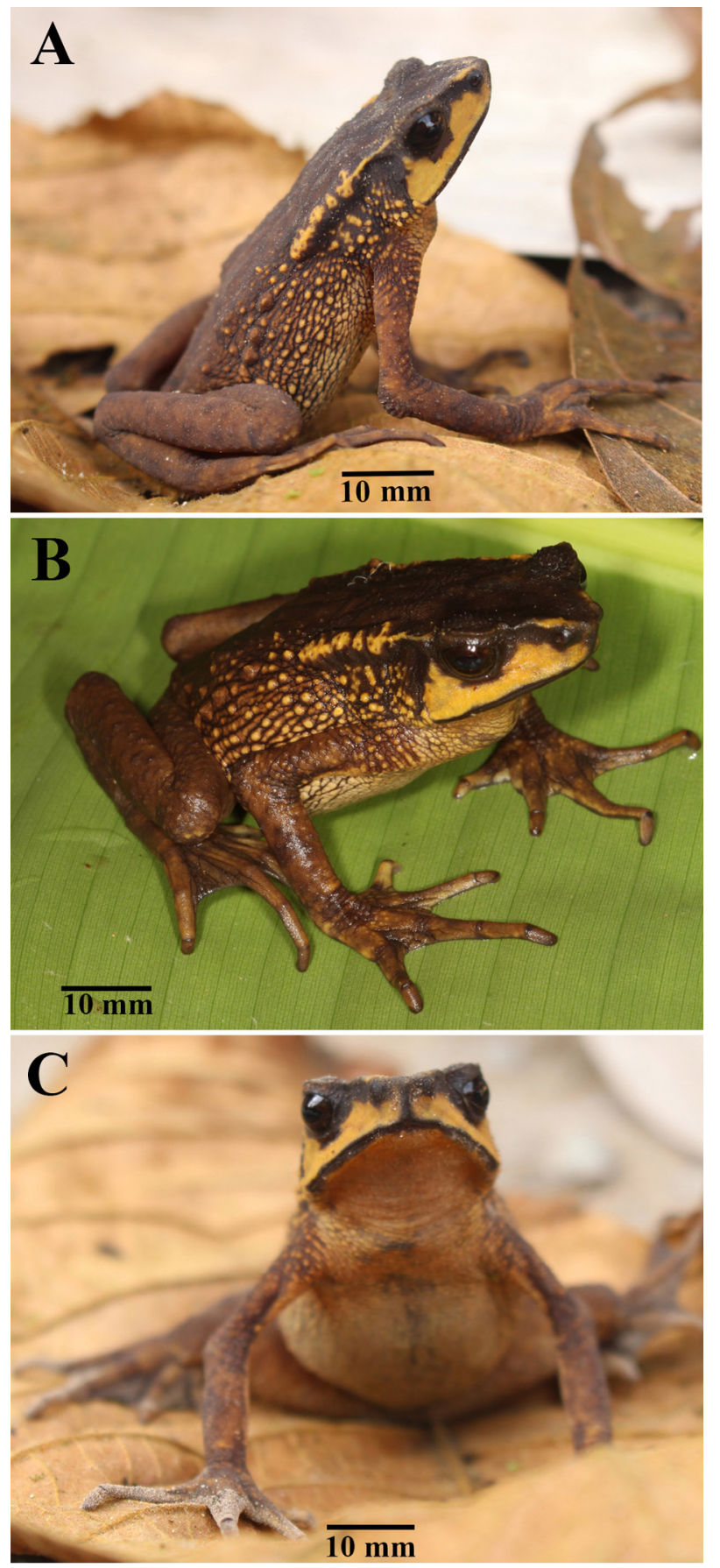

Figure 3. Rhaebo colomai, adult female DHMECN 13828, LRC = $52.0 \mathrm{~mm}$. A, B. Dorsolateral views. C. Frontal view. Photographs by Carolina Reyes-Puig (A, C) and Gabriela Bittencourt-Silva (B).

area of occupancy was calculated as approximately 20 $\mathrm{km}^{2}$. Its habitat is suffering an accelerated and continued decline, mainly because the increase of mining concessions within this area (Vandegrift 2018). We infer, based on geographical data and deforestation statistics (Sierra 2013), that continuous decline of its habitat quality across most of its distribution has occurred over the last 10 years, and we suspect this is ongoing. With this new information, we recommend that $R$. colomai should be classified under the IUCN category Endangered, Blab (i, ii, iii, iv).

\section{Discussion}

After over 30 years without any records in Ecuador, our observations of Rhaebo colomai at 3 new localities highlight the need for urgent action to ensure its long-term conservation. Unfortunately, habitat loss and fragmentation in the province of Carchi is caused by unsustainable timber extraction, uncontrolled expansion of the agricultural frontier, and replacement by non-native plantations (Dodson and Gentry 1991, Kuecker 2007, MAE 2013, Sierra 2013). The Dracula Reserve seems to be the only protected area in Ecuador that might maintain populations of this threatened species. This reserve is managed by the Ecominga Foundation and is key for the conservation of not only amphibians in the area but also other rare and threatened taxa, such as orchids of the genera Dracula and Lepanthes, and the Spectacled Bear, Tremarctos ornatus (Cuvier, 1825) (Baquero and Gary, 2015).

We recommend urgent establishment of the following research and conservation actions to improve knowledge and promote conservation of $R$. colomai: (i) surveying other areas in the province of Carchi, Ecuador, and in the department of Nariño, Colombia; (ii) studying the life history, ecology, and population dynamics; (iii) developing a joint species conservation action plan between Ecuador and Colombia; (iv) expanding the Dracula Reserve to cover all surrounding areas in which the species inhabits and promoting the establishment of new public, communal and private reserves to protect remaining habitat; (v) promoting resource and habitat protection policies, especially focused on the conservation of watersheds; (vi) working with local landowners and governments to promote good practices for the management of forests and riverine areas; (vii) enhancing knowledge exchange between private and public stakeholders, including local governmental authorities, to promote research and conservation actions; (viii) raising local, national, and international awareness about the unique and rich biodiversity of the province of Carchi; and (ix) lobbying for the establishment, compliance, and enforcement of national, provincial, and local legislation that promotes protection and restoration of forests in the province of Carchi.

\section{Acknowledgements}

We thank 2 anonymous reviewers for their comments. We express our gratitude to the Fundación EcoMinga, in particular to Juan Pablo Reyes-Puig and Héctor Yela for their support to our research. Carolina Reyes-Puig thanks the project "Programa de Inventarios y Monitoreo del Sistema de Reservas Ecominga", executed by the Instituto Nacional de Biodiversidad and funded by University of Basel Botanical Garden, Rainforest Trust, and Fundación EcoMinga through the collaboration of Heinz Schneider, Lou Jost, Javier Robayo, and Mario H. Yánez-Muñoz. Eloy Nusirquia, María José Quiroz, Jhael Ortega, Santiago Guamán, Darwin Nuñes, and Katherin 
Hinojosa are thanked for their support during field and lab work. Field work by QCAZ, Pontificia Universidad Católica del Ecuador, was funded by a grant from SENESCYT (Arca de Noé Initiative; S. R. Ron and O. Torres-Carvajal principal investigators). J.W. Streicher was in part supported by an NSFDEB-NERC grant (NE/R002150/1). M. Wilkinson was funded by the Natural History Museum. Field work by S.T. Maddock was partially funded by University of Wolverhampton. Field work by H. Müller was made possible through a grant from the German Academic Exchange Service (DAAD). Field work by M. Torres-Sánchez was in part supported by Gans Collections and Charitable Fund. The travel to Ecuador by R. Kotharambath was made possible by the grant from the International Travel Support, Department of Science and Technology, Government of India. Research by Universidad San Francisco de Quito (USFQ) was supported by the Secretaría Nacional de Educación Superior, Ciencia, Tecnología e Innovación (Programa de Becas "Universidades de Excelencia", granted to D.F. Cisneros-Heredia) and the USFQ ("Impact of habitat changes on the biological diversity of the northern tropical Andes", project ID 1057; “Taxonomía, Biogeografía y Conservación de Anfibios and Reptiles", Project ID 48; USFQ Collaboration Grant and USFQ Research Publication Fund to Diego F. Cisneros-Heredia, principal investigator).

\section{Authors' Contributions}

$\mathrm{DFCH}, \mathrm{MW}$, and JWS raised funds for part of the investigation. CRP, MW, JWS, STM, GBBS, MTS, RK, HM, FNAL DAR, and SRR participated in the data collection. All authors wrote and contributed to the final version of the manuscript.

\section{References}

Baquero LE, Gary G (2015) Dracula smaug, Baquero \& Gary Mey, yna especie de orquídea ecuatoriana recientemente descubierta en la subtribu Pleurothallidinae. Orquideología 31 (2): 84.
Coloma L, Ron S, Yánez-Muñoz M, Cisneros-Heredia D (2004) Rhaebo colomai. The IUCN Red List of Threatened Species 2004. https:// www.iucnredlist.org/species/54462/11149772. Accessed on: 201901-14.

Dodson CH, Gentry AH (1991) Biological extinction in western Ecuador. Annals of the Missouri Botanical Garden 78 (2): 273-295.

Gassó-Miracle ME, Ostende L, Arntzen JW (2007) Type specimens of amphibians in the National Museum of Natural History, Leiden, The Netherlands. Zootaxa 1482: 25-68. http://doi.org/10.11646/ zootaxa.1482.1.2

Hoogmoed MS (1985) A new genus of toads (Amphibia: Anura: Bufonidae) from the Pacific slopes of the Andes in northern Ecuador and southern Colombia, with the description of two new species. Zoologische Mededelingen 59: 251-274.

Hoogmoed MS (1989) On the identity of some toads of the genus Bufo from Ecuador, with additional remarks on Andinophryne colomai Hoogmoed, 1985 (Amphibia: Anura: Bufonidae). Zoologische Verhandelingen (Leiden) 250: 1-32.

Kuecker GD (2007) Fighting for the forests: grassroots resistance to mining in northern Ecuador. Latin American Perspectives 34 (2): 94-107. https://doi.org/10.1177/0094582x06299081

Ministerio del Ambiente del Ecuador (MAE) (2013) Sistema de clasificación de los ecosistemas del Ecuador continental. Subsecretaría de Patrimonio Natural, Quito, 235 pp.

Murillo-Pacheco J, Cepeda-Quilindo B, Flores-Pai C (2005) Andinophryne olallai (Tandayapa Andes toad). Geographic distribution. Herpetological Review 36: 331.

Ron SR, Mueses-Cisneros JJ, Gutiérrez-Cárdenas PD, Rojas-Rivera A, Lynch RL, Rocha CD, Galarza G (2015) Systematics of the endangered toad genus Andinophryne (Anura: Bufonidae): phylogenetic position and synonymy under the genus Rhaebo. Zootaxa 3947(3): 347-366. http://doi.org/10.11646/zootaxa.3947.3.3

Sierra R (2013) Patrones y factores de deforestación en el Ecuador Continental, 1990-2010: Y un acercamiento a los próximos 10 años. Conservación Internacional Ecuador / Forest Trends, Quito, 45 pp.

Vandegrift R, Thomas DC, Roy BA, Mierya L (2018) The extent of recent mining concessions in Ecuador; Rainforest Information Center, Nimbin, New South Wales, Australia.

IUCN (2012) IUCN Red List Categories and Criteria: Version 3.1. Second edition. Gland, Switzerland / Cambridge, 32 pp.

IUCN Standards and Petitions Subcommittee (2017) Guidelines for Using the IUCN Red List Categories and Criteria. http://www. iucnredlist.org/documents/RedListGuidelines.pdf. Accessed on: 2019-01-24.

IUCN SSC Amphibian Specialist Group (2018). Rhaebo colomai. The IUCN Red List of Threatened Species 2018: e.T54462A85856993. http://doi.org/10.2305/iucn.uk.2018-1.RLTS.T54462a85856993. en. Accessed on: 2019-01-24. 